\title{
The Problem of Basic Education Policy and Its Implementation in Indonesia A Case Study in Tasikmalaya City
}

\author{
Maya Puspita Dewi \\ Doctoral Student of Public Administration Department \\ University of Padjadjaran \\ Bandung, Indonesia \\ puspitadewi09@gmail.com
}

\begin{abstract}
The purpose of this article is to understand the problems in implementation of education policy in Tasikmalaya City. The formulation, implementation, and evaluation on the fact of the matter is the struggle of various public interests in allocate and manage resources in accordance with the vision, hopes and priorities that want to be realized. Hence, the substance of a public policy will not be usefSul if not implemented. This research used qualitative methods with phenomenology approach. The data collected by observation, in-depth interviews and study of the library and analyzed by data reduction; presentation and conclusion/verification. The result showed that the education policy implementation in order to improve the quality of basic education in Tasikmalaya city is still not yet fully done well. Even though already have Local Regulation about education in Tasikmalaya City, but still many educators, school administrator and help keeper on the elementary school level from both sides of the numbers and competencies not meet the National Education Standard/ NES and Minimum Standard of Services/ MSS.
\end{abstract}

Keywords: implementation; public policy; basic education; Tasikmalaya City.

\section{INTRODUCTION}

Basic Education is the general education that ever nine years, held for six years in Elementary School/Madrasah Ibtidaiyah (SD/MI) and three years in the Secondary School/Madrasah Tsanawiyah (SMP/Mts) or education units that are equal as stated in Law No. 20/2008 about National Education System

The essence of basic education can be said as the gate for each of the learners to the development of himself in the future, and "provisions basis" to develop the attitude and ability and provide the knowledge and basic skills required to live in the community and prepare students who meet the requirements to participate in the next level of education.

Balancing efforts and elaboration opportunity of basic education in Indonesia is not only qualitative but also quantitative nuance. Expansion strategy and opportunity balancing quality basic education, including the development of alternative education, made as a vehicle for the actualization of the basis of education throughout the life. Therein lies the role of the government is very large to produce policies that are overwhelmingly in favor of education, especially basic education.

\footnotetext{
Corresponding authors: Maya Puspita Dewi
}

There are some problems of education in Indonesia, among others: the first is there is no spreading education opportunities, both in sufficient quantity and quality. This is due to the geographical conditions, social and culture of the people of Indonesia is heterogen and have consequence directly against its varieties the condition of Indonesian citizens. Second, the quality of education is still not excellent graduates at all levels. Even though the development of education has increasingly toward advancement, but still far from the hope of the community.

Third, low readiness of graduates in entering the continuation of study and life in society. Already very many graduates of education at all levels have produced, but they do not fully have sufficient readiness. Fourth, a weaker performance of educational institutions on all levels. Education Management has been attempted righting themselves, good infra structure and the system, implementation, and evaluation. But still very many educational institutions that do not have the independence in managing education productively [1].

In Tasikmalaya City, quality of basic education is still a problem. Starting from the problem of budget usage for, educational tools, education governance and also about quality of human resources (teachers and civil servants), and others. The indicator that there are still many problems that is because the excesses of the policy that is not implemented well. This is for example, can be seen from budget used for education Tasikmalaya City.

In 2012, the budget for Education Office reached IDR 480.339.384.951, 2013 to IDR 540.212.378.864, then 2014 and 2015 each reached IDR 648.959.363.203. In 4 years, an average of $89 \%$ used for indirect expenditure which consists of servant expenditure, salaries and benefits and additional income of Civil Servants. $11 \%$ is used for direct expenditure consists of expenditure for the employees, procurement of goods and services and capital spending. As a result, Tasikmalaya City is 1 out of 3 most government's autonomous region that personnel expenditure ratio against the total spending habits the highest in Indonesia namely $66.07 \%$.

The purpose of this article is to understand the implementation of education policy in Tasikmalaya City. According to Saefullah in Tachjan [2], that formulation, 
implementation, and evaluation on the fact of the matter is the struggle of various public interests in allocate and manage resources in accordance with the vision, hopes and priorities that want to be realized. The best whatever the substance of a public policy will not be useful if it is not implemented.

Based on the above issue, so the researchers intended to analyze how well the basic education policy in Tasikmalaya City implementing for improvement of education quality especially basic education.

\section{RESEARCH METHOD}

This research used qualitative methods with phenomenology approach. Phenomenology approach used to understand the meaning of each of the patterns of behavior that is indicated by the actors to formulate policies and policy practitioners in the implementation of education policy in the Tasikmalaya City.

While phenomenology naturalistic allows researchers to find the true meaning of (meaning) from each of the existing phenomenon [3]. The data collected through observation, indepth interviews and study of the library. While the data analysis through the 3 main steps namely data reduction; presentation of data and the withdrawal of the conclusion/verification.

\section{RESULT AND DISCUSSION}

In the process of public policy, the policy implementation is the steps are practical and differentiated from the formulation of policies that can be viewed as a stage of a theoretical nature. Anderson proposed that policy implementation is the application of the policy by the government's administrative machinery to the problem [4].

Grindle said, study of the process of the implementation of the policy to be determined include research and analysis of the implementation of programs in the concrete that has been planned as the values to achieve the goal of wider policy objectives [5]. Implementation, Frederich stated that the policy is an action that leads to the purpose of that proposed by a group or the government in a particular environment in relation to the specific barriers while looking for opportunities to reach the purpose or achieve the desired objectives [6]. While Dunn proposed that: "The implementation of the policy is the implementation of the control policy action in the time frame of the electric charge they carry obliges" [7]. Next, Hogwood and Gunn stated that the policy is a set of government actions that are designed to achieve specific results [8].

So, the implementation can be intended as an activity that is associated with the settlement of a work with the usage of tools to obtain the result. When the sense of the implementation of the above combined with the public policy and the implementation of public policy can be interpreted as a settlement activities or the implementation of a public policy that has been assigned/approved by the usage of tools to achieve the goal of the policy.

A lot of researcher who was focused on education policy implementation, for example, Suranto [9]; Sukmana [10]; Acetylena [11]; Prastiyono,[12]; Sulistyadi, 2014 [13]; Solichin [13]; Hamid [15]; and Pramudiana [16]. Previous research generally focused on inclusive education and free education, but this research focus on the implementation of basic education policy which was held by the local government through the education.

Based on the public policy studies, especially education policy with education management learns about the education management in the macro. The principles of education management is not different with the principles that are on the concept of management in general, so also with the functions of the education management is also a series of the concept of the formulation of the management. The implementation of the management in the field of education is directed to the effort to support the achievement of the purpose of education, while for the function and strategy from the concept of managerial skills on the same in principle applied in the scope of the management [17].

This aspect of education is the study of the management of education is public goods not private goods. In this context, education is goods and services common property (public), which the society has the right to get education and teaching (Article 31 Constitution), and education is the obligation of the government to hasten, mainly fundamental role provides the opportunity to learn about. Because education is public goods, then it must enter education policy studies in public policy perspective in the dimensions of the study of education management that multi-disciplines.

The development of education in the City of Tasikmalaya conducted by referring to the medium-term Development Plan Area (RPJMD) Year 2013-2017 which is intended to strengthen the education development with emphasized efforts to improve the quality of human resources including the development of the ability of science and technology and strengthening the competitiveness of the economy and social piety with refers to the vision and mission of the Tasikmalaya mayor.

Vision of Tasikmalaya Mayor is based on faith and one, realizing economic independence Competitiveness Toward Civil Society, and three mission to realize the vision, namely: (1) realize trustful governance (trusted), along with the creation of increased obedience and piety social community; (2) increase and provide the infrastructure and economic growth suprastruktur community empowerment based environmentally; (3) increase infrastructure and service quality education, health, social welfare and the development of local culture.

The education office as the executive authority of the Tasikmalaya Mayor in education that is set in the Regulation of the Tasikmalaya Mayor No. 62013 about the main task of the function and the details of the City Education Unit Task Tasikmalaya has the obligation to realize the vision and mission of the construction is especially third mission. The perspective to the front of the development of education is intended to develop intellectual aspect, but also the formation and development of characters, character, moral ethics, social and cultural attitudes and even physical fitness learners and independence in order to grow natural healthy and harmonious. In other words, education aimed to build and create smart human and moral, that is. a healthy human both physical and spiritual.

In particular, the education policy implementation in order to improve the quality of basic education in Tasikmalaya city is not done well yet. The reflection of the problems of education in 
the Tasikmalaya City can be seen in the medium-term Area Development Plan (RPJMD) Tasikmalaya City is shown on the Table 1 following.

Table 1. The education problems in Tasikmalaya city based on RPJMD

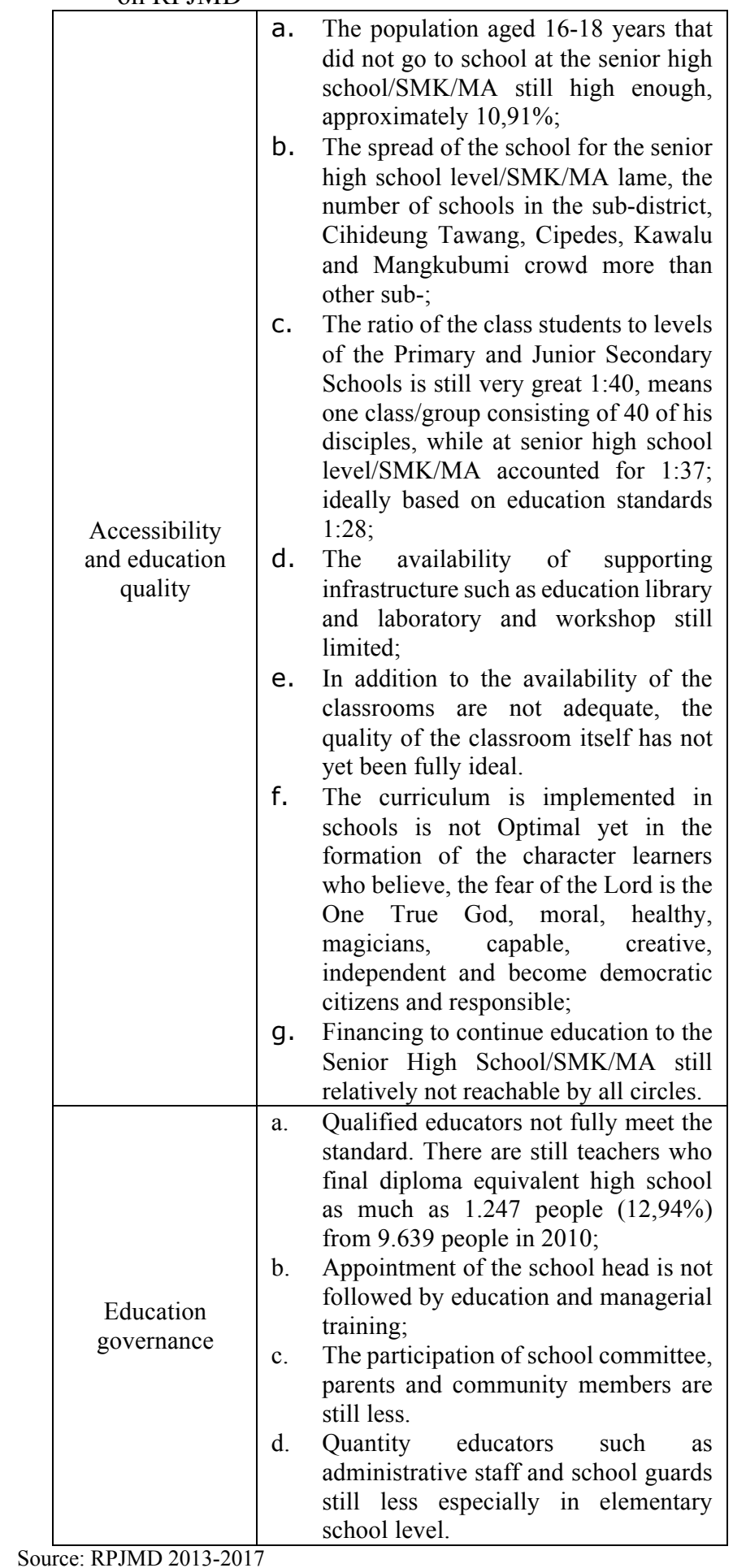

The problems of education in the RPJMD more clarified again in the strategic plan of Tasikmalaya City Education as presented in Table 2 as following:
Table 2. The Strategic Plan of Tasikmalaya City Education

\begin{tabular}{|c|c|}
\hline $\begin{array}{l}\text { The fulfillment of the } \\
\text { Education } \\
\text { Infrastructure in the } \\
\text { context of the } \\
\text { fulfillment of the } \\
\text { minimum standard of } \\
\text { services (MSS) and } \\
\text { National Education } \\
\text { Standards (NEP) }\end{array}$ & $\begin{array}{l}\text { a. Most of the primary schools in } \\
\text { the City of Tasikmalaya does } \\
\text { not have special rooms science } \\
\text { laboratory, that meet the } \\
\text { standard; } \\
\text { b. Most of the primary schools in } \\
\text { the City of Tasikmalaya does } \\
\text { not have a School Library space } \\
\text { that meet the standard; } \\
\text { c. Most of the primary schools in } \\
\text { the City of Tasikmalaya does } \\
\text { not have special room's } \\
\text { principals, which meet the } \\
\text { standard. Most of the primary } \\
\text { school head space unites with } \\
\text { teachers room; } \\
\text { d. Most of the primary schools in } \\
\text { the City of Tasikmalaya does } \\
\text { not have the space of } \\
\text { jurisprudence that meet the } \\
\text { standard; } \\
\text { e. Most of the Junior High School } \\
\text { in the City of Tasikmalaya does } \\
\text { not have special rooms } \\
\text { language laboratory and } \\
\text { equipment of supporters who } \\
\text { meet the standard; } \\
\text { f. Most of toilet students, toilet } \\
\text { teachers in SD/Junior High } \\
\text { School in the City of } \\
\text { Tasikmalaya has not meet the } \\
\text { MSS/SNP; Most of the worship facilities } \\
\text { g. Most } \\
\text { (mosques) in SD/Junior High } \\
\text { School in the City of } \\
\text { Tasikmalaya has not meet the } \\
\text { MSS/SNP; } \\
\text { h. Most SD/Junior High School in } \\
\text { the City of Tasikmalaya has not } \\
\text { been equipped with the } \\
\text { tools/space appropriate } \\
\text { supporting SNP. }\end{array}$ \\
\hline $\begin{array}{l}\text { Governing and civil } \\
\text { servant teachers } \\
\text { Mapping }\end{array}$ & $\begin{array}{l}\text { Governing and PNS teachers } \\
\text { balancing between education units, } \\
\text { between level and between the type } \\
\text { of education in the unit of } \\
\text { education for primary and } \\
\text { secondary schools, conventional } \\
\text { due to the excess teachers are yet to } \\
\text { be implemented. }\end{array}$ \\
\hline $\begin{array}{c}\text { Over quota learning } \\
\text { classes and Learners } \\
\text { per single. }\end{array}$ & $\begin{array}{l}\text { Some schools (from junior to hig } \\
\text { school) especially state schools } \\
\text { have the number of students per } \\
\text { with } 435 \text { students exceed the terms } \\
\text { of NES and MSS namely exceed } \\
32-36 \text {, should } 27 \text {. }\end{array}$ \\
\hline $\begin{array}{l}\text { The acceleration and } \\
\text { alleviation of the nine- } \\
\text { year compulsory } \\
\text { learning program. }\end{array}$ & $\begin{array}{l}\text { a. The nine-year compulsory } \\
\text { learning program has not been } \\
\text { completed } 100 \% \text {; } \\
\text { b. The achievement of gross } \\
\text { participation number (AN } \\
\text { APK) and pure Participation }\end{array}$ \\
\hline
\end{tabular}

the City of Tasikmalaya does ot have special rooms science that meet the the City of Tasikmalaya does not have a School Library space

the City of Tasikmalaya does not have special room's meet the teachers room jurispruden standard;

in the City of Tasikmalaya does not have special rooms teachers in SD/Junior High School in the City of Tasikmalaya has not meet the School in the City of Tasikmalaya has not meet the

the City of Tasikmalaya has not been equipped with the appropriate Governing and PNS teachers secondary schools, conventiona be implemented. have the number of students per with 435 students exceed the term $32-36$, should 27. The achievement of gross APK) and pure Participation education for primary and 
Table 2. Continued

\begin{tabular}{|c|l|}
\hline & $\begin{array}{l}\text { Number (APM) has not } \\
\text { completed 100\%; } \\
\text { c. The Old number of schools } \\
\text { (ALS) reaching the range of 8- } \\
\text { 9 years. }\end{array}$ \\
\hline The problem of & $\begin{array}{l}\text { a. Many schools in any level does } \\
\text { not have administrative staff } \\
\text { school/Business Governance } \\
\text { staff that meet the SNP and } \\
\text { MSS from both sides of the } \\
\text { numbers and the competencies; } \\
\text { every level of school } \\
\text { b. Many schools in any level has } \\
\text { no power executing aiding, } \\
\text { couriers' schools. }\end{array}$ \\
\hline
\end{tabular}

Source: Strategic plan of education agency of Tasikmalaya city 20132017

In spite of already have Local Regulation Number 4 Year 2007 about education in Tasikmalaya City as one rule to implementation of basic education but still many educators, school administrator and help keeper on the elementary school level from both sides of the numbers and competencies not meet the NES and MSS. So also with the fact that there are still many Elementary Schools that do not have the means and infrastructure according to the standard of such as special rooms science laboratory, school library, rooms of school Principals, rooms of school administrator. In the other part, the curriculum implemented in schools is not optimal.

\section{CONCLUSION}

The function and purpose of the implementation is to establish a relationship that allows the goals or objectives of public policy (politics) can be realized as outcome from activities carried out by the government. The implementation of education policy in Tasikmalaya City has not been fully implemented well yet. This result is in the still low-quality education especially basic education in Tasikmalaya City. Despite the education budget is enlarged every year, but it is not enough to improve the quality of basic education in the Tasikmalaya City. So, it need a greater effort to solve them.

\section{REFERENCES}

[1] R. Wahab, "The Direction of the Policy and Strategy of basic education, medium and high in Indonesia", A paper presented on 25 July 2004 at Center for Social Welfare Training (Balai Besar Diklat Kesejahteraan Sosial), Yogyakarta. 2004

[2] Tachjan, "Public Policy Implementation", Bandung: AIPI, 2016, p.X

[3] R.C. Bogdan and K.S. Biklen, "Qualitative Research for Education: An Introduction to Theory and Methods" Boston London: Allyn Bacon, 1982.

[4] J. E. Anderson, "Public Policy Making”, Chicago: Holt, Rinehart and Winston, 1978, pp. 25.

[5] M.S. Grindle, "Politics and Policy Implementation in the third world", New Jersey: Princeton University Press, 1980, pp.6

[6] and [8] Wahab, Solichin Abdul Wahab, "Policy Analysis; From Formulation to Implementation Policy (Analisis Kebijakan: dari Formulasi ke Implementasi Kebijakan Negara), Jakarta: PT. BumiAksara, 2002, pp.49.

[7] W. N. Dunn, Public Policy Analysis (Analisis kebijakan Publik), Yogyakarta: Gadjah Mada Pers, 2000, pp.132.
[9] Suranto, "The Effect of Policy Implementation of Division of Authority of Education on Quality of Basic Education Service; A Study in Yogyakarta" (Pengaruh Implementasi Kebijakan Pembagian Kewenangan Bidang Pendidikan Terhadap Kualitas Pelayanan Pendidikan Dasar; Studi Di Kota Yogyakarta)", Universitas Padjadjaran, 2007.

[10] R. H. Sukmana, dkk. "Implementation of Compulsory Basic Education Policy Nine Years in Malang“" (Implementasi Kebijakan Wajib Belajar Pendidikan Dasar Sembilan Tahun Di Kota Malang). Jurnal Administrasi Publik (JAP), 2, (4), 2010, pp. 729-734.

[11] S. Acetylena, "Analysis of Implementation of Character Education Policy In Perguruan Taman Siswa Kecamatan Turen Malang Regency" (Analisis Implementasi Kebijakan Pendidikan Karakter Di Perguruan Taman Siswa Kecamatan Turen Kabupaten Malang", Jurnal Kebijakan dan Pengembangan Pe ndidikan Volume 1, Nomor 1 Januari 2013, 55-61 ISSN: 2337-7623; EISSN: 2337-7615.

[12] Prastiyono. "Implementation of Inclusive Education Policy; A Study at Galuh Handayani School Surabaya" (Implementasi Kebijakan Pendidikan Inklusif ; Studi di Sekolah Galuh Handayani Surabaya). Jurnal Administrasi Publik, Vol. 11, No. 1,2013 pp. 117 - 128.

[13] H.K. Sulistyadi, Implementation of the Implementation of Inclusive Education Service Policy in Sidoarjo Regency (Implementasi Kebijakan Penyelenggaraan Layanan Pendidikan Inklusif di Kabupaten Sidoarjo). Kebijakan dan Manajemen Publik.Volume 2, No. 1, 2014.

[14] M. Solichin, Implementation of the Implementation of Inclusive Education Service Policy in Sidoarjo Regency (Implementasi Kebijakan Pendidikan Dan Peran Birokrasi). Jurnal Studi Islam. Volume 6, No. 2, Oktober 2015.

[15] I.D. Pramudiana,. "Implementation of Inclusive Education Policy for Ship Crews in Surabaya" (Implementasi Kebijakan Pendidikan Inklusif Untuk ABK Di Surabaya. Dimensi Pendidikan dan Pembelajaran). Vol. 5 No. 1. 2017.

[16] A. Hamid. "Implementation of Regulation of North Penajam Paser Regent Number 18 Year 2012 About Free Education Entrepreneurship in Nenang Subdistrict Penajam Sub-Province North Penajam Paser District" (Implementasi Peraturan Bupati Penajam Paser Utara Nomor 18 Tahun 2012 Tentang Penyelengaraan Pendidikan Gratis di Kelurahan Nenang Kecamatan Penajam Kabupaten Penajam Paser Utara). eJournal Ilmu Pemerintahan, Volume 3, No 2: 2015, pp. 623635.

[17] M. Sutapa, "Education Policy in Policy Perspective" (Kebijakan Pendidikan Dalam Perspektif Kebijakan), Jurnal Manajemen Pendidikan, No. 02/Th IV/Oktober/2008, pp. 12-16. 